\title{
Characteristic effects of the microencapsulated diazinon against the German cockroach, Blattella germanica L.
}

\author{
Masuko Sakurai, ${ }^{*}$ Mineko Kurotaki, ${ }^{*}$ Shiro Asaka, ${ }^{*}$ \\ Tokuko Umino* and Toshiaki Ikesho ji** \\ *Ageo Research Laboratory, Agrochemicals Division, Nippon Kayaku Co., Ltd., \\ Koshikiya, Ageo, Saitama 362, Japan \\ ** Department of Agricultural Biology, the University of Tokyo, \\ Yayoi, Bunkyo-ku, Tokyo 113, Japan
}

(Received: May 8, 1982)

\begin{abstract}
Microencapsulated diazinon (MC) showed superior residual effect to emulsifiable concentrated diazinon (EG) against the German cockroaches. The observation of the body-cleaning behaviour of cockroaches, the chemical analysis of diazinon and the microscopic observation of the MC proved the easy attachment of the MC to their body surface and the massive ingestion into their digestive tracts. Thus, the MC in the guts of cockroaches plays an important part of its killing activity as the $\mathrm{MC}$ on the body surface does. Due to this bimodal entry, the short-contact and residual toxicities of $\mathrm{MC}$ are fortified over that of $\mathrm{EC}$.
\end{abstract}

\section{INTRODUCTION}

Recently, for the purpose of improving safety at use of insecticides and obtaining the residual effects against insects, studies of microencapsulation of insecticides have been progressed.

The microencapsulated diazinon (abbreriated as MC) was developed by Pennwalt Co. (USA) for the use of hygienic insect control.

Lowell et al. (1980), and Rust and Reierson (1979), as cited by Pest Control (Anonymous, 1980), reported that $\mathrm{MG}$ reduced the mammalian toxicity hazards of insecticides.

Bennett and Runstrom (1979), Rust and Reierson (1979), and Lowell et al. (1980) reported the excellent control effect and residual effect of $\mathrm{MG}$ against cockroaches in the field. Umino and Kobayashi (1982) con-

* 桜井益子，黒滝美音子，浅香四郎，海野登久子： 日本化薬株式会社農薬事業部 上尾研究所（テ362 埼王県上尾市小敷谷字堀込 225-1)

** 池庄司敏明 : 東京大学農学部農業生物学科害虫学 教室（干113 東京都文京区弥生 1-1-1） firmed its residual effect in the laboratory test. As to the mode of action of $\mathrm{MC}$ against cockroaches, Lowell et al. (1980) mentioned that its stomach poison activity results in the surprisingly high control effect against even diazinon-resistant cockroaches.

This work was done to clarify the modus opcrandi of $\mathrm{MC}$ against the German cockroaches in comparison with emulsifiable concentrated diazinon by observation of the behaviour of cockroaches in contact with the chemicals and by the quantitative analysis of residual diazinon.

\section{Materials and Methods}

Insects and insecticides: The male German cockroaches, Blattella germanica L., of a diazinon-susceptible colony were used at 2 to 3 weeks after their last ecdysis. These insects were reared and tested at $25 \pm 1^{\circ} \mathrm{C}$ and at $65 \pm 5 \%$ R.H. The insecticides used were a microencapsulated diazinon (KNOX OUT ${ }^{\circledR}$ 2FM, Pennwalt Co.) and an emulsifiable concentrated diazinon (Tanabe Phar- 
maceutical Co., Ltd.).

Bioassay: The insecticide formulation was diluted with water to $0.5 \%$ of the active ingredient, and sprayed uniformly onto a glass plate $(10 \times 10 \times 0.3 \mathrm{~cm})$ with a glass atomizer at a rate of $50 \mathrm{ml} / \mathrm{m}^{2}$. These treated plates were kept under the room conditions for the following bioassay.

(1) Confined contact test

The plates at $24 \mathrm{hr}$ after treatment were used. Ten cockroaches were enclosed by a glass ring (9-cm diameter, $6-\mathrm{cm}$ height) on the treated plates for various hours, and the $50 \%$ knock-down time and mortality at 24 hr were observed.

(2) Residue contact test

A number of the treated plates were stored under the room condition up to 34 weeks. At a certain interval, 2 plates at a time were rendered for the quantitative analysis of residual diazinon and other 2 plates for the assay of residual effect. The bioassay was done as above.

\section{(3) Non-contact test}

This test was performed for checking the vapour effect of the two formulations. On the treated glass plate, a glass ring $(9-\mathrm{cm}$ diameter, $1.5-\mathrm{cm}$ height) was set and covered with a wire mesh (0.7-mm mesh). On top of this mesh, another glass ring (9-cm diameter, 6-cm height) was placed and ten cockroaches were released onto the mesh so that only the effect of insecticide vapour could be evaluated. $\mathrm{KT}_{50}$ and mortality at $24 \mathrm{hr}$ were determined.

(4) Mouth-closed contact test

On ether-anesthesia, the mouths of cockroaches were closed with an instant glue using a needle to deny their ingestion of $\mathrm{MC}$. After their recovery from anesthesia they were subjected to the confined contact test.

Observation of $M C$ ingestion behaviour and dissection of the cockroaches: The cockroaches were exposed to either EC- or MCtreated plates for a certain period. They were observed by a video system in the dark but under illumination with an infrared light. After removing the digestive tracts of the MC-exposed cockroaches we rinsed them in physiological salt solution to free extraneous tissues as completely as possible and observed the attached MC and analyzed the amount of diazinon.
Staining of $M C$ : To observe the ingested $\mathrm{MC}$ in situ under a light microscope, the MC was stained with Kayanol Red BL (CI No. acid red 265 Nippon Kayaku Co., Ltd.) before exposure to the cockroaches. For staining of $\mathrm{MC}$, Kayanol Red $\mathrm{BL}$ was mixed with $\mathrm{MC}$ to $0.5 \%$, and heated at $50^{\circ} \mathrm{C}$ for 2 days.

Scanning electron microscopy (SEM): Both $\mathrm{MG}$ and cockroach preparations were coated with gold-palladium using an ion coater (IB-3, Eiko) and examined with a scanning electron microscope (JSM-U3, Jeol) at an accelerating voltage of $25 \mathrm{kV}$.

Analysis of diazinon in $M C$ and $E C$ on glass plates and in cockroaches: The cockroaches were exposed to either EC- or MCtreated plates for a certain period. The glass plates and cockroaches' body surface were washed with $100 \mathrm{ml}$ of ethyl acetate. Whereas, the digestive tracts and the remained parts of bodies were homogenized with 100 $\mathrm{ml}$ of acetone. These extracted solutions were injected into the gas chromatograph equipped with flame photometric detector.

The column used was a glass, $1 \mathrm{~m} \times 2 \mathrm{~mm}$ i.d., packed with $2 \%$ QF-1 on Gaschrome Q. Operating temperatures for the column and detector were $150^{\circ} \mathrm{C}$ and $240^{\circ} \mathrm{C}$, respectively. Flow rate of gases were, $\mathrm{N}_{2}, 55 \mathrm{ml} / \mathrm{min}$; $\mathrm{H}_{2}, 80 \mathrm{ml} / \mathrm{min}$, Air, $50 \mathrm{ml} / \mathrm{min}$, respectively.

\section{Results and Discussion}

Observation of $M C$ by a scanning electron microscope: The observation of MG by the SEM indicated that there were two types of capsules; one type had smooth surface and another had rough surface. According to the analysis of diazinon content, the smoothsurface $\mathbf{M C}$, which was separated from the rough-surface $\mathrm{MC}$ by picking one by one with an insect pin under a microscope, contained more diazinon than rough-surface MC. Further, the diameter of these capsules were heterogenous, ranging 5-30 $\mathrm{m}$ (Fig. 1a).

Evaluation of the residual efficacy: The $\mathrm{MC}$ on the glass plates gave $100 \%$ mortality and quick knock-down effect even at 34 weeks after the treatment in 24-hr continuous contact. On the other hand, the EG lost efficacy at 4 weeks after the treatment 


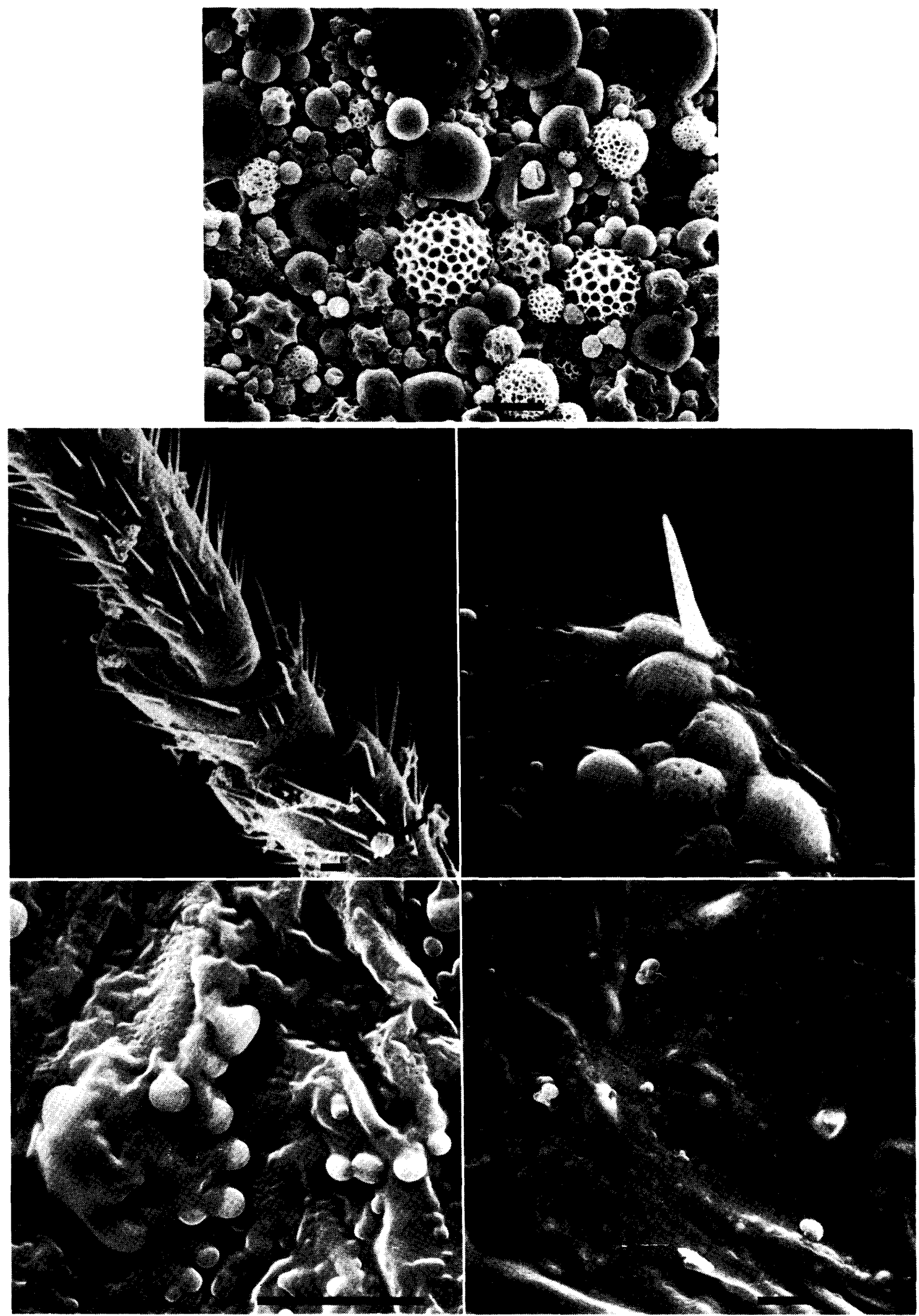

Fig. 1 Some observations of MC by the SEM. Bars represent $0.2 \mu \mathrm{m}$

a, MC on the glass plate $\times 420: \mathrm{b}, \mathrm{MC}$ on a part of foreleg of cockroach. Arrows show MC particles $\times 170 ; \mathrm{c}, \mathrm{MC}$ on a wing surface of cockroach $\times 1,760 ; \mathrm{d}, \mathrm{MC}$ on inner surface of crop wall of cockroach $\times 1,260$ : e, MC in a part of midgut wall of cockroach $\times 420$. 
(Fig. 2). These results were parallel to the quantities of residual diazinon; the percentage of residual diazinon of $\mathrm{MC}$ on the glass plate was $60 \%$ or more even at 34 weeks after the treatment, while that of EC rapidly decreased in 1 week and disappeared within 4 weeks.

$K T_{50}$ values of the diazinon formulations in different contact tests: As shown in Table 1, the mouth-closed cockroaches took 65 min more to knock down than the intact cockroaches did when they contacted MC. But in the case of $\mathrm{EC}$, there were no significant difference between the $\mathrm{KT}_{50}$ values of these cockroaches. From the different effects of these formulations we presume that the oral uptake of MC by the cockroaches causes the fast knock-down effect.

The results of non-contact $t \in$ sts showed that the vapour effect of diazinon was much repressed in the $\mathrm{MC}$ compared with the $\mathrm{EC}$; the $\mathrm{KT}_{50}$ values were $545 \mathrm{~min}$ vs. $320 \mathrm{~min}$, respectively. The long residual effect of the $\mathrm{MC}$ is attributed to this repressed evapora-

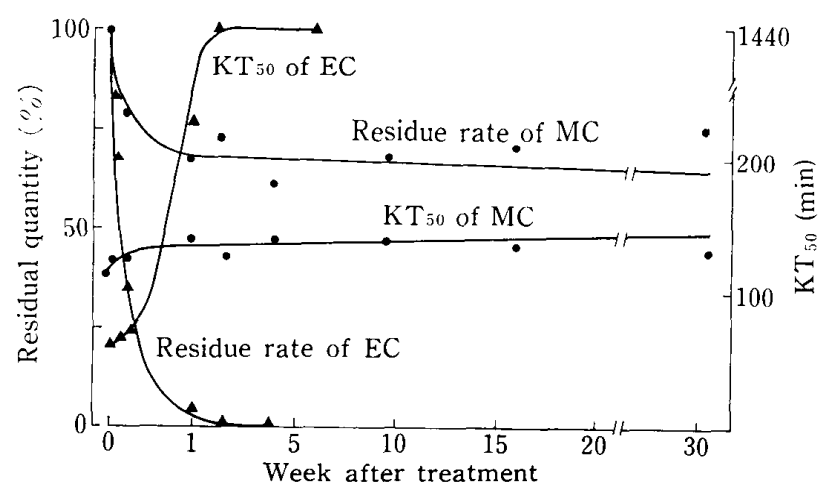

Fig. 2 Residual effect of MC and EC against the German cockroaches by the residue contact test (shown by $\mathrm{KT}_{50}$ ) and the percentage of the residual quantity of diazinon on the treated glass plate

Table 1 Knock-down effects of MC and EC against the German cockroaches in different tests

\begin{tabular}{lcr} 
& \multicolumn{2}{c}{$\mathrm{KT}_{50}(\mathrm{~min})$} \\
\cline { 2 - 3 } \multicolumn{1}{c}{ Test method } & $\mathrm{MC}$ & $\mathrm{EC}$ \\
\hline Confined contact & 100 & 84 \\
Mouth-closed contact & 165 & 91 \\
Non-contact & 545 & 320
\end{tabular}

tion of diazinon.

Behaviour of the cockroaches on the residue: While observing the cockroaches' behaviour in contact with the diazinon formulations under an infrared light, we counted the frequency of cleaning of their legs and antennae by their mouths. The cockroaches on the $\mathrm{MC}$ residue cleaned their forelegs 3 to 5 times more frequently than those on the EC residue or an untreated plate as shown in Fig. 3. The cockroaches on the $\mathrm{MC}$ cleaned their forelegs 12 times for the first $15 \mathrm{~min}$, while those on the EC and in control did only 3 and 5 times, respectively. As they were exposed longer and so intoxicated, the cleaning frequency gradually decreased. Other body parts, such as antennae, middle- and hind-legs were also cleaned but less frequently and there were no significant difference between the respective frequencies. Figure $1 \mathrm{~b}$ shows a part of the foreleg of cockroach which contacted the MC-treated plate. Many $\mathrm{MC}$ are seen attaching on the leg surface and sticking to the hairs. Less number of $\mathrm{MG}$ could also be seen on other parts of body surface such as a wing (Fig. 1c). It is one of the characteristics of MC that they adhere the body surface of cockroaches easily. The cockroaches are also observed to preen or groom continuously to remove foreign substances from their body. Therefore, this characteristic of MC undoubtedly promotes the cleaning behaviour of cockroaches.

$M C$ in the alimentary tracts of cockroaches: A number of $\mathrm{MC}$ were easily ob-

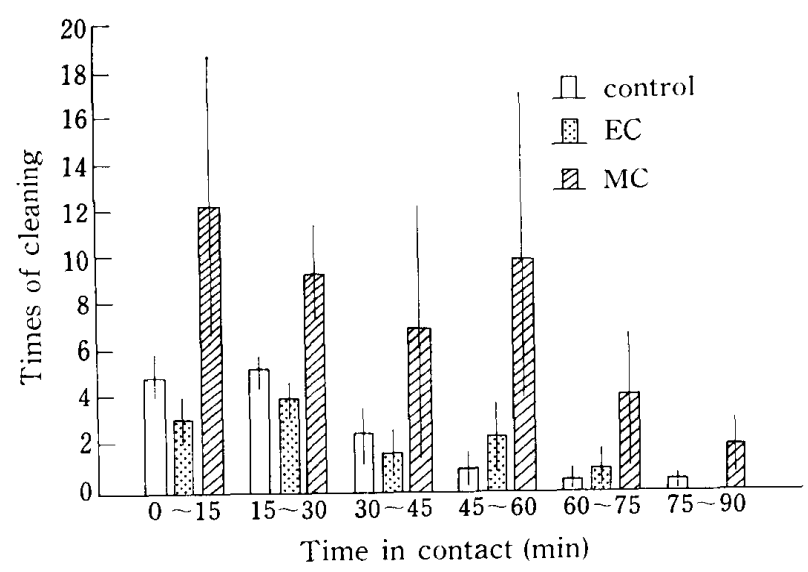

Fig. 3 Frequency of foreleg-cleaning of the German cockroaches in contact with the diazinon formulations 
served in the alimentary tract of a cockroach which had contacted MC.

Figures 1d and e are SEM-photographs of a part of the crop wall and an anterior part of the midgut wall. We could also make the passage of $\mathrm{MC}$ visible in the alimentary tract of a cockroach by oral administration of the stained $\mathrm{MC}$ and dissection of the cockroaches. The process is illustrated in Fig. 4. Passing through the foregut, the $\mathrm{MC}$ reached the midgut within $10 \mathrm{~min}$ and remained there in quantity. Then these capsules were gradually passed into the midgut, which was accompanied by dilatation of the foregut. At about $100 \mathrm{~min}$ after the administration, the $\mathrm{MC}$ reached the pylorus of midgut and the cockroaches knocked down. One or two large bubbles were observed in the crop $30 \mathrm{~min}$ after the treatment. The similar bloating of the crop has been observed in a parathion-treated Madeira cockroach by Hopkins (1961). According to them, those bubbles accumulate carbon dioxide and air due to the prolonged intoxication of the cockroach. In conjunction to the previous observations in the increased frequency of their foreleg cleaning, we confirmed here the engorgement of the $\mathrm{MC}$ into their digestive tracts and found the MC to act as a stomach poison as well as a dermal poison. As to the absorption and metabolism of an organic phosphorus insecticide ronnel in the digestive tracts of cockroaches, Hopkins et al. (1970) reported that the foregut wall is highly permeable to orally ingested ronnel which is dissolved in polyethylene glycol. While, the midgut degrades ronnel to the water-soluble metabolites.

Therefore, the large accumulation of the MC in the crop and similar penetration of diazinon through the crop is thought to intoxicate the cockroaches. The cockroaches became hyperactive at $95 \mathrm{~min}$ and knocked down at $105 \mathrm{~min}$.

Measurement of diazinon in the cockroaches contacted $M C$ and EC: After washing the body surfaces and removing the alimentary tracts, we measured the diazinon content of the remaining parts of body, which we considered as the absorbed diazinon in the body. The result is shown in Fig. 5. When the absorbed diazinon increased to about $2 \mu \mathrm{g} /$ cockroach (shown in an open bar), $50 \%$ of the cockroaches were knocked down in both MC and EC. It took about $70 \mathrm{~min}$ with the EG and $100 \mathrm{~min}$ with the MC. However, the mouth-closed cockroaches in contact with $\mathrm{MC}$ did not attain $2 \mu \mathrm{g}$ of the absorbed diazinon within 100 min. Naturally, the $\mathrm{KT}_{50}$ of the mouthclosed cockroaches was larger than that of the intact cockroaches; 165 vs. $100 \mathrm{~min}$. In

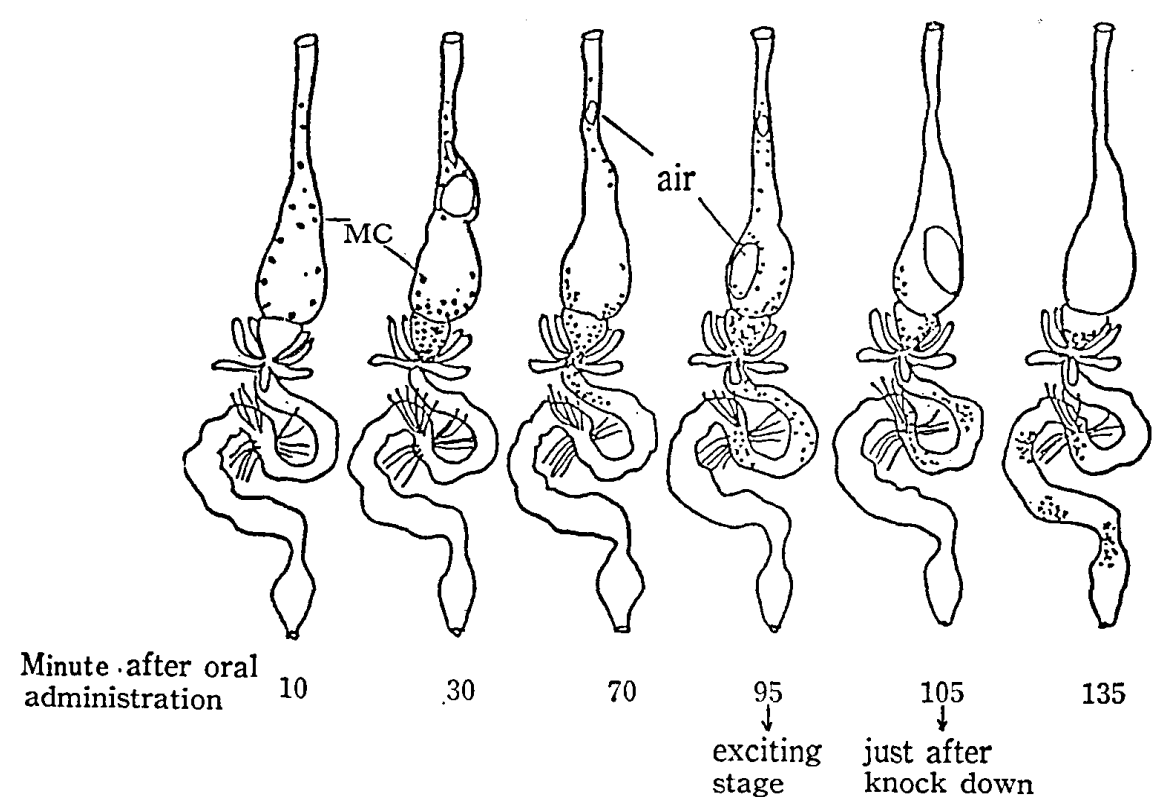

Fig. 4 The scheme of the movement process of $\mathrm{MC}$ in the digestive tract of cockroaches by the oral administration of stained $\mathrm{MC}$ 


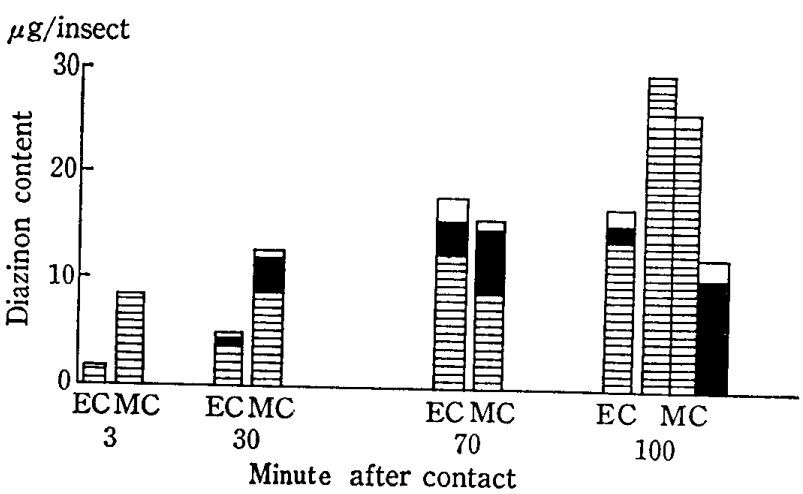

Fig. 5 Diazinon recovered from the body surface (位), the digestive tract $(\square)$, and the remaining parts of body ( $)$ of cockroaches which contacted EC and $\mathrm{MC}$ for various periods

In this case, $\mathrm{KT}_{50 \mathrm{~s}}$ were $70 \mathrm{~min}$ in $\mathrm{EC}$ and $100 \mathrm{~min}$ in $\mathrm{MC}$.

the alimentary tracts of cockroaches, the diazinon content of $\mathrm{MC}$ was much larger than that of EC, the diazinon content of the body surface was also higher in the MC-exposed cockroaches than in the EC-exposed ones except those at $70 \mathrm{~min}$. These results are in accordance to their cleaning behaviour and the microscopic observations of $\mathrm{MC}$ in the alimentary tracts.

The extremely large quantity of diazinon on the body surface of the MC-exposed cockroaches at $100 \mathrm{~min}$ was, however, caused by their knock-down or slip-down on the treated plates.

Short contact experiment: The short contact experiment was done by the confined contact test and the results are shown in Table 2. When the contact period was only $3 \mathrm{~min}$ or less, the mortality was $100 \%$ and the $\mathrm{KT}_{50}$ was 220 to $270 \mathrm{~min}$ with the $\mathrm{MC}$. On the contrary, with the EC, it took 10 min contact to obtain $100 \%$ mortality. The large quantity of the MC engorged by cockroaches and adhered to their body surfaces as measured in the preceding analysis (Fig. 5) ensured the complete mortality of cockroaches even in such a short contact period.

As the conclusion, the spraved $\mathrm{MC}$ adheres to the body surface and is ingested into their alimentary tracts by their forelegcleaning behaviour more than the EC is. Thus, the MG is more effective, if not fastacting, and residual against cockroaches than the EG diazinon.
Table 2 Effects of $\mathrm{MG}$ and EG against the German cockroaches in the short contact experiments

\begin{tabular}{ccccr}
\hline $\begin{array}{c}\text { Contact } \\
\text { time } \\
(\min )\end{array}$ & $\begin{array}{c}\mathrm{KT}_{50} \\
(\min )\end{array}$ & $\begin{array}{c}\text { Mort. } \\
\text { at } 24 \mathrm{hr} \\
(\%)\end{array}$ & $\begin{array}{c}\mathrm{KT}_{50} \\
(\mathrm{~min})\end{array}$ & $\begin{array}{c}\text { Mort. } \\
\text { at 24 hr } \\
(\%)\end{array}$ \\
\hline 1 & 270 & 100 & $1,440<$ & 1 \\
2 & 230 & 100 & $1,440<$ & 1 \\
3 & 220 & 100 & $1,440<$ & 2 \\
10 & 214 & 100 & 305 & 100 \\
20 & 130 & 100 & 98 & 100 \\
\hline
\end{tabular}

\section{Acknowledgements}

We wish to express sincere thanks to Prof. Y. Matsumoto and other members of the Applied Entomology Laboratory, Department of Agricultural Biology, the University of Tokyo for their kind accommodation.

\section{REFERENGES}

Anonymous (1980): KNOX OUT ${ }^{\circledR} 2 \mathrm{FM}$ is $\mathrm{mi-}$ croencapsulated diazinon. Pest Control, 48(3) : 24-25.

Bennett, G. W. and E. S. Runstrom (1979): New developments in pest control insecticides. Pest Control, 47(6): 14-20.

Hopkins, T. L. (1961): Functions of the Madeira cockroach alimentary tract in the absorption, metabolism, and excretion of Ronnel. $J$. Econ. Entomol., 54(2): 224-230.

Hopkins, T. L., N. R. Rao and J. J. Ameel (1970): Physiological effects of Parathion on the cockroach gut in vivo and correlation with external symptoms of poisoning. J. Econ. Entomol., 63 (4) : 1086-1091.

Lowell, J. R., C. B. de Savigny and G. D. Curl (1980): KNOX OUT® 2FM insecticide; a new microencapsulated formulation of diazinon. In: Proceedings of Am. Chem. Soc., 179th Meeting.

Rust, M. K. and D. A. Reierson (1979): Insecticide candidates for German cockroach control in apartments. Pest Control, 47(5) : 14-16.

Umino, T. and K. Kobayashi (1982): Efficacy of microencapsulated diazinon against German cockroach Blattella germanica L. Jap. J. Sanit. Zool., 33(2) : 139-143. 


\section{摘 要}

ダイアジノンマイクロカプセル剤のチャバ ネゴキブリに詨する効力の特徵について

ダイアジノンマイクロカプセル剤 (MC)のチャバネ ゴキブリに対する効力の特性を明らかにする目的で, ダイアジノン乳剤 (EC) を対照薬剤として, 種々の効 力試験, 薬剤接触時のゴキブリの行動観察, 虫体の腹 部解剖および走查電子顕微鏡による $\mathrm{MG}$ の観察, ガ スクロマトグラフィーによるダイアジノン分析を実施 した.

残効性試験の結果，温度 $25 \pm 1{ }^{\circ} \mathrm{C}$, 湿度 $65 \pm 5 \%$ の条件下で，EC はほぼ 4 週以内に効力が消失したの に対し，MCは34週後も60\%以上の残留率を保持し，
100\% の殺虫効力を示した. ت゙キブリが MC に淔接 接触すると，無数の MG が体表に付着するため，ゴ キブリが前脚を口でぬぐう頻度が増し, 消化管内に多 量の $\mathrm{MC}$ が取り込まれ，嗉暈部に貯留する.

この消化管内の $\mathrm{MG}$ と，体表に付着した $\mathrm{MC}$ との 影響で, 致死効力が発現する. それに対して ECは, 主として体表および気門からの作用が中心となる。

MCに掠いて, diazinonのゴキブリ虫体への侵入経 路が，経口および経皮によることから，3 分以内の短 時間接触においても，確実な致死作用をもたらすこと と，カプセル化によって diazinonの揮散が抑制され， すぐれた残効性を示すことが明らかになった.

以上のことから， MC は EG にくらべてゴキブリ に対する効力が増強されていることが認められた. 